YEARBOOK

of ANTITRUST

and REGULATORY

STUDIES

www.yars.wz.uw.edu.pl
Peer-reviewed scientific periodical, focusing on legal and economic issues of antitrust and regulation. Creative Commons Attribution-No Derivative Works 3.0 Poland License.

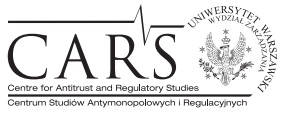

Centre for Antitrust and Regulatory Studies, University of Warsaw, Faculty of Management www.cars.wZ.uw.edu.pl

\title{
2010 Amendments to the Polish Energy Law
}

\author{
by
}

Filip Elżanowski*

\section{CONTENTS}

I. General remarks

II. The Act of January 8, 2010 on amending the Energy Law and on amending certain other acts

1. The amendment's general aims and premises

2. The particulars of the procedure for changing the seller

3. Changes to the procedure for obtaining the terms for connecting a source to the electricity grid

4. Changes in the procedure for designating an operator of a transmission system distribution system, storage system, system for liquefying natural gas, or the operator of a combined system

5. The introduction of a system of support for generating electricity in high-efficiency cogeneration by units burning methane from mines or gas obtained from processing biomass

6. The introduction of the support system for generating agricultural biogas

7. The implementation of Directive 2005/89/EC of the European Parliament and of the Council of January 18, 2006 concerning measures to safeguard security of electricity supply and infrastructural investment

7.1. Introduction

7.2. New definitions

8. Removing the state of threat to the security of electricity supplies

9. The new powers and obligations of the URE President

10. Introducing the requisite public trade of electricity by generators in the aim of preventing the phenomenon of unjustified increase of stranded costs

* Dr. Filip Elżanowski, Faculty of Law and Administration, University of Warsaw; advocate. 
10.1. Ratio legis for introducing the obligation of public trade of electricity and the subject and object scope of the obligation

10.2. Allowable forms for trade in electricity by virtue of Art. 49a para. 1 and 2 of the Energy Law

11. The manner for carrying out the obligation resulting from Art. 49a para. 1 and 2 of the Energy Law

12. Exemption from the scope of the obligation defined in Art. 49a para. 1 and 2 of the Energy Law

13. The information and report obligations

III. The Act of April 9, 2010 on making available economic information and exchanging economic data

IV. Summary

\section{General remarks}

In 2010 the Polish Parliament passed just two amendments to the Act of April 10, 1997 - the Energy Law ${ }^{1}$ (hereafter, the Energy Law). The first of them is the Act of January 8, 2010 on amending the Energy Law and on amending certain other acts ${ }^{2}$. The second change to the Energy Law was enacted by virtue of the Act of April 9, 2010 on making available economic information and exchanging economic data ${ }^{3}$. The first of the above amendments, the work into which had begun early in 2009 , has significantly influenced the functioning of the electricity market in Poland. This amendment has a manifold character and in a comprehensive manner regulates a range of issues that will be discussed in this paper. However, the change enacted by virtue of the second of the two amendments herein referred to is minor and concerns one of the aspects of how energy undertakings operate.

Passage of the Act of January 8, 2010 on amending the Energy Law and on amending certain other acts was the outcome not only of the necessity to adapt the provisions of the Energy Law to the demands of European legislation, but also stemmed from the practical needs of the market's functioning. In the past years certain disadvantageous trends had become observable in the behavior of those participating on the market, including speculative activities when reserving the grid power of wind farms in the electricity system, and the sale of electricity by producers to a trade company in the framework of a single market group at a price substantially lower than the price which was determined outside the given group for users and end users (this practice

\footnotetext{
1 Journal of Laws 2006 No. 89, item 625, as amended.

2 Journal of Laws 2010 No. 21, item 104.

3 Journal of Laws 2010 No. 81, item 530.
} 
leads to an increase in the compensations received by producers through stranded costs, which will be described in detail below). It therefore became necessary to introduce appropriate changes to the Energy Law, ones aimed at eliminating phenomena having an unfavorable impact on the way the energy market functions in Poland.

Below I shall describe the extensive amendment to the Energy Law that was enacted by virtue of the Act of January 8, 2010 on amending the Energy Law and on amending certain other acts. Beyond that, and in keeping with chronological order, I shall in brief describe the change enacted by virtue of the Act of April 9, 2010 on making available economic information and exchanging economic data.

\section{The Act of January 8, 2010 on amending the Energy Law and on amending certain other acts}

\section{The amendment's general aims and premises}

The Act of January 8, 2010 on amending the Energy Law and on amending certain other acts is one of the most extensive and most comprehensive amendments to the Energy Law passed to date. The changes enacted by virtue of this Act have significantly influenced the functioning of the electricity market in Poland - indeed, in some areas in has altered its shape.

The Act on amending the Energy Law and on amending certain other acts has implemented Directive 2005/89/EC of the European Parliament and of the Council of January 18, 2006 concerning measures to safeguard security of electricity supply and infrastructural investment ${ }^{4}$. The Act also contains changes serving the implementation of amendments from Regulation 1228/2003/EC of the European Parliament and of the Council of June 26, 2003 on conditions for access to the network for cross-border exchanges in electricity ${ }^{5}$, introduced by the decision of the European Commission, November 9, 2006 .

In regard to the implementation of the above directives and to the experiences with the functioning of hitherto applied solutions in the amending act, the following issues have been regulated:

- the enabling of operators of electricity systems to undertake efficient and effective measures in cases when there is a shortfall of electricity in the system;

\footnotetext{
4 OJ [2006] L 33/22.

5 OJ [2003] L 176/1.

${ }^{6}$ OJ [2006] L 312.
} 
- the introduction of divided competencies and imposing responsibility for assuring the security of electricity supplies upon all essential users of the electricity system and organs of public administration;

- the guaranteeing of indicating the operator of the system for all networks and gas and electricity installations and assuring them independent functioning.

Moreover, as indicated in the grounds for the act herein described, its purpose is also to:

- streamline the procedure for changing the seller of gas fuels and energy;

- curb speculative activities when reserving the grid power of wind farms in the electricity system;

- create the legal bases for connecting biogas facilities to low-pressure gas transmission systems, whether existing or being built at local initiative (this is to enable the supply of this energy provider for users in rural areas, especially regions where the supply of natural gas is not possible), and to introduce a system for supporting biogas based on a system of 'tradeable certificates' (in Polish: zbywalne świadectwa) on the origin of agricultural biogas generated in biogas facilities;

- embrace methane released from mines and the gas obtained from processing biomass with a system of support within the framework of high-efficient cogeneration;

- prevent the phenomenon of selling electricity by its generators to a trade company within the framework of a single market group at a price substantially lower than the price which was determined outside the given group. This phenomenon leads to reduction of revenues for the generator, which in turn have an impact on the amount of compensations paid to cover the stranded costs on the basis of the Act of June 29, 2007 on the bases for covering the costs arisen among producers in regard to premature dissolution of long-term contracts for selling power and electricity. In regard to such "vertically integrated" producers, the obligation was introduced to sell a defined portion of the generated electricity by auction or at goods markets.

\section{The particulars of the procedure for changing the seller}

The law on changing a seller (the right to choose a seller) is one of the most important powers recipients (buyers) of electricity possess, and it is the basis for the functioning of the liberalized market of electricity services. It creates the conditions for real competition between energy undertakings and gives consumers of electricity and gas fuels the opportunity to lower the costs that result from their use. 
The right to change a seller was introduced to the Energy Law via an amendment from March $2005^{7}$ as an implementation of the obligation stemming from Directive 2003/54/EC of the European Parliament and of the Council of June 26, 2003, concerning the joint principles for the internal electricity market, lifting Directive 96/92/EC ${ }^{8}$ - that is, the electricity Directive. The right to choose a seller was included in Art. $4 \mathrm{j}$, which awards recipients the right to purchase gas fuels or energy from a seller of their own free choice. This regulation in a scope embracing industrial recipients has been in effect since July 1, 2004, and has embraced household recipients since July 1, 2007.

Before this amendment was passed, the provision of Art. $4 \mathrm{j}$ of the Energy Law, stipulating the right to choose a seller, was quite laconic: 'The recipients of gas fuels and/or energy have the right to purchase those fuels or energy from a seller of their own choosing'. In accord with the doctrine of energy law we note that this provision cannot stand alone in the sense that the legal aspects of making avail of the law on changing a seller are contained in other provisions of the Energy Law and executive acts 9 .

The amended version of art $4 \mathrm{j}$ of the Energy Law introduced the following new elements:

- the definition that the dissolution of a contract on the basis of which an energy undertaking supplies gas fuels or electricity to the recipient of such fuels or energy takes place without carrying additional costs;

- the definition of the maximum period for dissolving a contract, on the basis of which an energy undertaking supplies gas fuels or electricity to the recipient of such fuels or energy in a household;

- the introduction of additional obligations in regards to sellers of energy and system operators.

As mentioned, one of the fundamental elements introduced into the provision pertaining to the right to change a seller is that of stipulating explicite that the final recipient may dissolve a contract on the basis of which an energy undertaking supplies said recipient with gas fuels or energy, without bearing other costs and compensations than those which result from the contents of the contract. As concerns the manner for changing a seller, the amendment was limited to stipulating that the final recipient may dissolve a contract on the basis of which an energy undertaking supplies said recipient with gas fuels or energy by submitting a written statement to the energy undertaking.

7 Act of March 4, 2005 on amending the Energy Law, and the Act on environmental protection (Journal of Laws 2005 No. 62, item 552).

8 OJ [2003] L 176/37

9 A. Walaszek-Pyzioł [in:] M. Wierzbowski, R. Stankiewicz [eds], Wspótczesne problemy prawa energetycznego [Contemporary issues in energy law], Warszawa 2010, p. 174. 
Moreover, the act on amending the Energy Law and on amending certain other acts introduced a provision regarding the period for dissolving a contract with the seller to date. In accordance with Art. 4j(4) of the Energy Law said contract undergoes dissolution upon the final day of the month following the month in which the recipient's statement reached the energy undertaking. The recipient may, however, indicate a later date for the contract's dissolution.

Here it need ne stressed that the power to dissolve a contract with the hitherto seller of electricity without bearing additional costs and with keeping the above described period for dissolution was granted only to final recipients in households. This decision of the legislator was dictated by the fact that granting such power to all recipients of energy, including industrial recipients, would de facto entail granting them the right to dissolve long-term contracts with sellers of electricity, and this would create a dangerous breach of the principle pacta sunt servanda and destabilize the long-term contract market.

The manner for changing the seller as defined in Art. $4 \mathrm{j}$ of the Energy Law also finds application in regards to recipients embraced by DSOs, as per Art. $\mathrm{Bb}$ of the Energy Law - that is, the ones adopted in line with meeting the needs for unbundling, or separating distribution undertakings from the structure of undertakings that are vertically integrated.

In regards to the extension, by virtue of the amendment here described, of the principles concerning the right to change a seller, new obligations were introduced for grid undertakings (DSOs and the operator of the transmission system). By virtue of Art. $4 \mathrm{j}(2)$ of the Energy Law the energy undertaking dealing in the transmission or distribution of gas fuels or energy is obliged, in applying objective and transparent principles that assure equal treatment of system users, to enable the recipient of gas fuels or energy connected to its grid to change the seller of gas fuels or energy on terms and in a manner defined in the systemic electricity and gas regulation. Moreover, the seller of gas fuels carrying out the sale of such fuels to final recipients connected to the distribution or transmission grid, or the seller of energy carrying out its sale to final recipients connected to the distribution grid, is obliged to place on its website information on the prices for the sale of gas fuels or energy and the about the terms for their application, as well as to make the same available for public view at its headquarters.

In regards to the changes introduced by virtue of the provision of Art. $4 j$ of the Energy Law, the catalogue of obligations resting on undertakings performing the role of distribution system operators (DSOs) was expanded - Art. 9c(3)(9a)(e)-(f) of the Energy Law. In accordance with this provision the DSO, in applying objective and transparent principles that assure equal treatment of system users and heeding the demands of environmental 
protection, is responsible for enabling the performance of contracts for the sale of electricity agreed by recipients connected to the grid through:

- implementation of the terms and manner for changing a seller of electricity and heeding them in the instruction for such movement;

- placement on website and making available for public view at its headquarters the following: an up-to-date list of sellers of electricity with which the operator has concluded contracts on providing services of distributing electricity, information about the seller from the electricity office in the region where the DSO operates, and samples of contracts concluded with users of the system, particularly samples of contracts concluded with final recipients and with sellers of electricity.

The above described amendments to the law on changing a seller pose, however, but partial application of Poland's legal status in this scope to EU requirements. Poland is obliged to carry out the implementation of provisions of the Third Energy Package, which contains further changes to the procedure described here.

\section{Changes to the procedure for obtaining the terms for connecting a source to the electricity grid}

The amendment described here to the Energy Law has introduced farreaching changes in the procedure for obtaining the terms for connection to the electricity grid regulated in Art. 7 of the Energy Law.

As noted in the grounds for the acts on amending the Energy Law and on amending certain other acts, in regard to the introduced system of support for renewable energy sources a significant increase has been observed in issuance of terms for connecting wind farms, including by a significant number of subjects which do not possess the financial possibilities for realization of such. These subjects treat the obtained terms for connection as a trade good. And yet the reserving of a defined amount of power in a given location for a subject that is not carrying out investments blocks the capacity for connection to the grid and limits the connection of other new sources of energy. This phenomenon is unfavorable from the point of view of developing power generation, including the development of renewable sources of energy.

In regards to the above, the institution of connection terms and its legal character were made more specific. In accordance with Art. 7(3a) of the Energy Law the subject applying for connection to the grid is obliged to submit a request for definition of the terms for connection to the grid. This request for definition of the terms for connection is to include in particular denotation of the subject applying for connection, definition of properties, the object or 
locale, to which gas fuels or energy are to be supplied, along with information essential for assuring that all technical and exploitative demands are met.

The terms for connection are valid for two years from the day of their issue [Art. 7(8h) of the Energy Law]. The issue of terms for connection takes place in the form of a statement of intent on the part of the energy undertaking handling the transmission or distribution of electricity (TSO or DSO). The provision of Art. 7(8i) of the Energy Law defines the legal character of the terms for connection: in the period of their validity they pose the civil law obligation of the energy undertaking to conclude a contract on connecting a given subject to the electricity grid.

As already mentioned at the beginning of this paper, the amendment to the Energy Law has introduced the institution of a 'payment in the form of a fee' for connection to the electricity grid, which is intended to prevent the phenomenon of blocking connections capacities by subjects not in possession of financial means permitting the construction of a power generation source. Therefore, obliged to suspend this payment are only those subjects that are applying for connection to the electricity grid of a source generating more than $1 \mathrm{kV}$ [Art. 7(8a) of the Energy Law].

The manner for reckoning the payment in the form of a fee for connection to the electricity grid has been defined in law, and so has its maximum level. In accordance with Art. 7(8a) of the Energy Law the amount of the payment in the form of a fee comes to 30zł for each kilowatt of power transmitted, as defined in the request for definition of connection terms. The amount of the down payment may not however be greater than the amount of the anticipated fee for connection to the grid, and cannot exceed 3,000,000zł. The down payment is submitted within seven days from the day the request is submitted for definition of connection terms, on pain of the request not being considered [Art. 7(8c) of the Energy Law].

With regard to the significant amount of the down payment, especially as pertains to large projects, provision Art. 7(8j) of the Energy Law defines the terms for the down payment's return - namely, in the case when the energy undertaking:

- refuses to issue connection conditions or to conclude a contract on connection to the electricity grid with a subject applying for connection for the reason of a lack of technical or economic terms for connection, it is obliged to immediately return the down payment taken;

- issues connection terms after the time period, it is obliged to pay interest on the down payment reckoned for each day of delay in issuing said terms;

- issues connection terms that will be a matter of contention between the energy undertaking and the subject applying for their issue and the dispute will be resolved in favor of the subject, it is obliged to return 
the payment taken together with interest reckoned from the day said payment was made until the day of its return, insofar as connection does not occur.

As concerns the subjects obliged to make such payment - that is, subjects applying for connection of an energy source to the electricity grid of a voltage higher than $1 \mathrm{kV}$ - another scope of documentation essential for obtaining connection terms has also been defined. In accordance with the provision of Art. 7(8d) of the Energy Law the relevant subjects are obliged to attach to their request for definition of connection terms in particular:

- an extract and sketch of the local spatial plan;

- in the case such a plan is absent, a decision concerning the terms for construction and utilization of the area for the immovable property defined in the request, if such is required on the basis of regulations for planning and zoning.

The extract and sketch of the local spatial plan or decision concerning the terms for construction and utilization of an area are to confirm the permissibility of the locality of the given energy source on the area embraced by the planned investment, which is in turn embraced by the request for the definition of connection terms.

Connected with the detailing of the procedure for issuing connection terms are new obligations on the operators of electricity systems in this scope. The energy undertaking is obliged to issue connection terms within a time period of [Art. 7(9g) of the Energy Law]:

- 30 days from the day the request for definition of connection terms is submitted by the request-submitter being connected to a grid with a voltage not exceeding $1 \mathrm{kV}$, and in the case of connecting a source from the day of tendering the down payment;

- 150 days from the day the request for definition of connection terms is submitted by the request-submitter being connected to a grid with a voltage exceeding $1 \mathrm{kV}$, and in the case of connecting a source - from the day of tendering the down payment.

In both of these instances the time periods indicated bind the energy undertaking, if the request for connection is complete. For exceeding the time period for issuing connection terms the energy undertaking is subject to a penalty of not less than 3,000zł for each day of delay in issuing connection terms (Art. 56 of the Energy Law).

Moreover, the energy undertaking dealing in the transmission or distribution of electricity (TSO and DSO) assures and finances the drafting of expert studies into the impact on the electricity system of the equipment, installations, or grids connected directly to the electricity grid of a voltage greater than $1 \mathrm{kV}$ with the exception of: 
- generating units to be connected of a joint installed power not greater than $2 \mathrm{MW}$, or;

- equipment of the final recipient of a joint transmission power not greater than $5 \mathrm{MW}$.

Obligations regarding making information available have also been placed upon energy system operators. In particular, the TSO and DSO is obliged to draw up information concerning:

- subjects applying for connection to the electricity grid of a voltage greater than $1 \mathrm{kV}$, the localization of connections, transmission power, the dates of issuing connection terms, concluding contracts on connection to the grid, and commencing the supply of electricity;

- the amount of available transmission power for electricity stations or their groups that enter into the compass of the grid with a voltage greater than $110 \mathrm{kV}$, and also planned changes of their amounts forecast over the upcoming 5 years, from the day such data are published.

Operators are to draw up this body of information in accordance with the regulations concerning the protection of secret information or other information that is protected by law. The undertaking is to update such information once per month and to place such on its website, and also to make it available for public view at its headquarters.

\section{Changes in the procedure for designating an operator of a transmission system distribution system, storage system, system for liquefying natural gas, or the operator of a combined system}

The Act on January 8, 2010 on amending the Energy Law and on amending certain other acts has introduced a range of changes in the procedure for designating an operator of a transmission system distribution system, storage system, system for liquefying natural gas, or the operator of a combined system. The basic objectives of this amendment in the scope of the new principles for designating the above-mentioned operators are:

- adapting the Energy Law to the requirements of the Third Energy Package;

- assuring that the tasks of systems operators are carried out according to the Energy Law;

- assuring that the system operators enjoy independence;

- improving the safety conditions of electricity supplies;

- eliminating 'gaps' - that is, areas for which no operator has been designated;

- assuring the exclusivity of a single transmission operator on the territory of Poland. 
Above all, the amendment has introduced the possibility for the owner of a given network or installation to entrust another energy undertaking to perform the obligations of operator in making avail of such network or installation. Owing to this the catalogue of subjects allowed to perform the function of operator (of whatever kind) has been expanded. Among those who may become such an operator are foremost: the owner of a transmission grid, the owner of a distribution grid, the owner of a storage facility or installation for liquefying natural gas who possesses a concession for conducting business activity in making avail of such grid or installation. Beyond that list, others who may become such an operator include: an energy undertaking possessing a concession for conducting business activity in the scope of transmitting or distributing gas fuels or electricity, storage of gas fuels, liquefying natural gas, and re-gasification of natural gas, with which the owner of a transmission system, distribution system, storage system, or system for liquefying natural gas, has concluded a contract entrusting said energy undertaking to perform the obligations of operator in making avail of the grid or installation it owns.

However, the possibility of entrusting the performance of the obligations of operator is not unlimited. Entrusting the performance of the obligations of operator may pertain to carrying our business activity in the scope of distributing electricity if the number of recipients connected to the electricity grid of the energy undertaking is not greater than 100,000 , or in the scope of distributing natural gas if the number of recipients connected to the gas network is not greater than 100,000 and the sale of gas fuels does not exceed $100 \mathrm{mln} \mathrm{m}^{3}$ annually.

The contract on entrusting the performance of the obligations of operator is to define, in particular, the area in which the given operator will be carrying out business activity, along with the principles for carrying out the principles of equal treatment of recipients, with itemization of the obligations entrusted to be carried out directly by the operator of a transmission system or distribution system [Art. 9h(5) of the Energy Law].

The manner for designating operators was defined in Art. 9h(1) of the Energy Law. A suitable operator is designated by the President of the Urzędu Regulacji Energetyki (Energy Regulatory Office; hereafter, the URE President) on the motion of the owner of the transmission grid, distribution grid, storage facility for gas fuels, or natural gas liquefaction facility. Such designation takes place by way of an administrative decision for a defined time period, one not to exceed the period for which the concession is valid. Moreover, within this decision the area is defined in which the business activity will be carried out.

The Act stipulates that within the territory of the Republic of Poland designation is made of only one operator of the gas transmission system or 
one operator of the combined gas system, and one operator of the electricity transmission system or one operator of the combined electricity system.

Generally, the designation of the operator of a given network or installation takes place on the basis of the decision of the URE President issued on the motion of the owner of said installation or network. In accordance with Art. $9 \mathrm{~h}(6)$ of the Energy Law the owner of a network is obliged to table a motion to the URE President concerning the designation of an operator within a period of 30 days from the day the decision of the URE President is handed down on awarding that owner a concession to carry out business activity in making avail of those networks or installations, or from the day in which the owner concluded a contract on entrusting the performance of the obligations of the operator.

Together with designating a given energy undertaking as an operator, the URE President, in accordance with the guidelines contained in the Energy Law, takes into purview the economic effectiveness of that undertaking, its efficaciousness in managing gas systems or energy systems, along with the security of the supply of gas fuels or electricity, the operator's fulfillment of the terms and criteria of independence, and the range of the obligations of its concession. However, the President of the URE refuses to designate a given undertaking as an operator if the undertaking does not possess the appropriate economic or technical means, does not guarantee effective management of the system, or does not meet the terms and criteria of independence.

Moreover, the designation of an operator may take place by way of a decision issued by the URE President ex officio (Art. 9h(1)-(5) and (7)-(9) of the Energy Law). The URE President designates ex officio, by way of administrative decision, an energy undertaking possessing a concession for transmitting or distributing gas fuels or electricity as operator of the relevant transmission system or distribution system in two instances. Firstly, in the case when the owner did not submit a motion to designate an operator of a gas system or the operator of an electricity system who would carry out business activity in making avail of its network and installation. Secondly, in the case when the URE President has refused to designate an operator that would carry out business activity in making avail of the network or installation in the motion. In issuing such a decision the URE President defines the area, installations, or networks in which the operator will be carrying out business activity, along with the terms for meeting the criteria of independence essential for performing the tasks of the operators of systems relevant to the scope of demands for the equal treatment of recipients and to scope of demands regarding environmental protection.

Through introducing changes in the procedure for designating the operator of a transmission system, the operator of a distribution system, the operator 
of a storage system, the system for liquefaction of natural gas, or the operator of a combined system the above described amendment was targeted above all at enabling a change of seller within the area of each network (by enabling a definition of the locally appropriate subject for performing the function of operator). In the longer term it was designed to enable the further development of elements of competition on the energy market. Moreover, the amendment here described introduced the legal determination that in Poland there is one operator of the gas transmission system and one operator of the electricity transmission system.

\section{The introduction of a system of support for generating electricity in high-efficiency cogeneration by units burning methane from mines or gas obtained from processing biomass}

The amendment being discussed also introduced significant changes in the system for supporting the generation of electricity in high-efficiency cogeneration. Most importantly, the scope of the support system was expanded by embracing within it the energy generating units in high-efficiency cogeneration thanks to methane released and captured during underground mining work in either active coal mines or those undergoing liquidation (and in some that have been liquidated). It also embraces energy generating units in high-efficiency cogeneration thanks to gas obtained from the processing of biomass [Art. 91(1)(1a) of the Energy Law]. The generators producing electricity in these units may obtain in this way certificates of origin in the form of so-called 'violet certificates'.

As indicated in the grounds for the act, distinguishing the support for methane from mines stems, on the one hand, from the need to avoid unfavorable consequences for the environment by the release of these gas fuels into the atmosphere or their use in less effective ways (in furnaces and the like). On the other hand, this stems from the divergent technologies and the costs of fuels in comparison with units burning natural gas or coal. Introducing a support system in the form of violet certificates is targeted at increasing the safety of mining work, the potential avoidance of emitting approx. 340 million $\mathrm{m}^{3}$ of methane annually into the atmosphere, as well as stimulating the development of taking advantage of these gases directly on location and obtaining them to generate energy in high-efficiency cogeneration. In Polish coal-mining some $810 \mathrm{mln} \mathrm{m}^{3}$ of methane are brought to the surface annually,

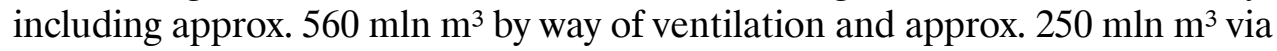
installations removing methane from mines. Methane removed from mining works by way of ventilation is entirely released into the atmosphere. Therefore, 
the potential in making avail of this fuel, on condition that a support system is functioning, is great.

The amendment also introduced regulations enabling a certain amount of electricity to be reckoned as belonging to high-efficiency cogeneration, as in this way it is embraced within the support system. The electricity here concerned arises from the generation of energy in a unit burning methane from mining or gas from processing biomass together with other fuels that do not qualify as belonging to the support system. Moreover, the provision of Art. 91(1b) states that for electricity produced in high-efficiency cogeneration in a unit burning gas fuels of a power less than $1 \mathrm{MW}$, as well as in a unit burning methane from mining or gas obtained from processing biomass, there seems to be but one certificate of origin from cogeneration. This provision is targeted at preventing the phenomenon of accumulating yellow and violet certificates in the case when a burning unit generating energy uses at least two different types of fuel that are embraced by the support system by virtue of Art. 91(1) of the Energy Law.

The functioning of this expanded support system was correlated with the entire functioning of the whole support system for generating electricity in high-efficiency cogeneration.

\section{The introduction of the support system for generating agricultural biogas}

By virtue of the Act of January 8, 2010 on amending the Energy Law and on amending certain other acts not only were changes introduced in the existing support system for generating electricity, but also a new support system was created in the form of certificates of origin of agricultural biogas (so-called 'brown certificates'). These certificates, in contrast to the other colored certificates, are not given for the reason of generating electricity, but the reason of generating agricultural biogas and its direction to the gas distribution network.

In regard to embracing agricultural biogas within the support system it became necessary to introduce to the dictionary a definition of agricultural biogas by specifying that it is a gaseous fuel obtained from raw materials and side products from agriculture, liquid or solid animal manure, side products or the remains of the agricultural and food processing industry, or biomass from forests in the process of methane fermentation.

The way the support system for generating agricultural biogas functions is in its basic aspects analogous to the support systems for generating electricity in renewable sources and in high-efficiency cogeneration (i.e., the manner for submitting requests for issuing certificates of origin, the manner for issuing 
certificates of origin, etc.). This system was correlated with the other such systems in the scope of subjects obliged to obtain and present for dismissal certificates of origin.

The basic difference between the support system for generating electricity in renewable sources and in high-efficiency cogeneration and the support system for generating agricultural biogas is the fact that the activity depending on generating agricultural biogas is, in light of the provision in Art. 9p of the Energy Law, a regulated activity (and not one that is on concession, as in the case of the generation of electricity). Conducting activity depending on the generation of agricultural biogas requires being entered into the registry of energy undertakings dealing in the generation of agricultural biogas, which is maintained by the President of the Agencja Rynku Rolnego (the Agricultural Market Agency; hereafter, ARR). The ARR President, as a registered organ, is obliged to convey to the URE President information on changes to the registry, to draft annual reports conveyed to the appropriate ministers and the URE President, and is authorized to inspect undertakings generating agricultural biogas.

\section{The implementation of Directive 2005/89/EC of the European Parliament and of the Council of January 18, 2006 concerning measures to safeguard security of electricity supply and infrastructural investment}

\subsection{Introduction}

The introduction to the Energy Law of the provision in Art. 11c, 11d, 11e, 11f, and Art. 3(16a)(16b)(16c), and (16d) by virtue of the Act of January 8, 2010 on amending the Energy Law and on amending certain other acts represents a transposition of the provisions of Directive 2005/89/EC of the European Parliament and of the Council of January 18, 2006 concerning measures to safeguard security of electricity supply and infrastructural investment. This Directive places on member-states the obligation to bring into effect statutory, executive, and administrative regulations essential for its application by February 24, 2008. Therefore, Poland, which introduced the necessary regulations not until January 8,2010 , significantly exceeded the timeframe stipulated in the Directive for implementation.

In regard to the implementation of Directive 2005/89/EC of the European Parliament and of the Council of January 18, 2006 concerning measures to safeguard security of electricity supply and infrastructural investment, to the Energy Law were introduced changes in the provision of Art. 11, provisions Art. 11d, 11e, 11f, and Art. 3(16a), (16b), (16c), and (16d) of the Energy 
Law. These provisions implement the definitions contained in Art. 2 of the Directive and also implement the determinations of Art. 3(1) of the directive that demand the assurance of a high level of security in the supplies of electricity by defining the obligations of users of the market and of the organs responsible for the security of electricity supplies, including the operational safety of the electricity grid in normal conditions, as well as in a situation imperiling the security of electricity supplies.

The provision of Art. 24 of Directive 2003/54/EC permits the application of security means in an essential range and places obligations to immediately inform the European Commission and EU member-countries. As raised in the grounds for the Act on amending the Energy Law and on amending certain other acts, the provisions binding in this range, Art. 9c, Art. 9g, Art 9j, and Art. 11 of the Energy Law, in the appraisal of electricity system operators and regulatory experiences of the URE President were insufficient and required extension.

The provisions of Art. 11c-11f of the Energy Law, added by virtue of the amendment of January 8, 2010, 'contain additional provisions concerning proceedings in situations of threat to the functioning of the electricity system and to the security of electricity supplies that may arise suddenly and require the immediate efforts of operators of electricity systems in order to prevent the outcomes of such threats. They also contain tasks in the scope of the operational security of the electricity grid' ${ }^{10}$.

\subsection{New definitions}

As mentioned above, in the aim of implementing the provisions of Directive 2005/89/EC to Art. 3 of the Energy Law, by virtue of the amendment here discussed legal definitions were introduced concerning the concepts of the security of electricity supplies, the security of the work of the electricity grid, and balancing the supplies of electricity with the needs for this energy [Art. 3(16a), (16b), (16d) of the Energy Law].

The definition of threat to the security of electricity supplies denotes the capacity of the electricity system to assure the safe functioning of the electricity grid and to balance the supplies of electricity with the needs for this energy. As results from the subject of the definition here in question, it is directly connected with two remaining issues: the safe functioning of the electricity system, and balancing the supplies of electricity with the need for this energy. Safe functioning (operational safety) signifies the uninterrupted work of the electricity grid, as well as the fulfillment of requirements in the scope of the

10 From the grounds to the Act of January 8, 2010 on amending the Energy Law and on amending certain other acts, Sejm print no. 2176, p. $31 \mathrm{ff}$. 
quality parameters of electricity and the quality standards in serving recipients, including permissible breaks in supplying electricity to end users, in the foreseeable conditions of the grid's operation. However, balancing the supplies of electricity with the need for this energy means satisfying the foreseeable current and long-term needs of recipients for electricity and power, without the need of undertaking efforts targeted at introducing limitations in supply and collection.

\subsection{Security threats to the supplies of electricity}

In accordance with Art. 11(1) of the Energy Law in the event of a threat to Poland's energy security, the security of its electricity supplies, the safety of persons, or the appearance of significant material losses on the Territory of Poland or its part, limitations in the sale of solid fuels may be introduced for a defined time, and also in the supply and collection of electricity or heat.

The provision of Art. 11c of the Energy Law regulates the situation of threat to the security of electricity supplies caused by events mentioned in para. 1 of that article, when the removal of said threat and the return of the correct functioning of the electricity system requires immediate efforts on the part of the system operator and the introduction of extraordinary means, and the necessary time for their introduction makes impossible application of the limitations in supplying and collecting electricity in a manner and scope defined in Art. 11(7) of the Energy Law ${ }^{11}$.

The provision of Art. 11c(1) of the Energy Law therefore defines in what situations may occur a threat to the security of electricity supplies, in particular:

- efforts stemming from the introduction of a state of emergency,

- a natural catastrophe or a direct threat of the occurrence of a technical failure in the meaning of Art. 3 of the Act of April 18, 2002 concerning natural disasters ${ }^{12}$,

- the introduction of an embargo, a blockade, limitation of lack of fuel supplies or electricity from another country on the territory of the Republic of Poland, or disturbances in the functioning of the electricity systems connected with the national electricity system;

- strikes or social unrest,

- the lowering of available reserves of generative capacity below the essential amount, as addressed in Art. $9 g(4)(9)$ of the Energy Law, or the lack of the possibility to make avail of them.

11 From the grounds to the Act of January 8, 2010 on amending the Energy Law and on amending certain other acts, Sejm print no. 2176, p. $31 \mathrm{ff}$.

12 Journal of Laws 2002 No. 62, item 558, with further amendments. 
In reference to the provision discussed here, we need note two fundamental questions. First, the catalogue contained in para. 1 has an open character ('especially in result of'), and secondly, the situations listed in it do not directly determine the existence of a threat to the security of electricity supplies, but rather only create the possibility of its existence ('may arise').

In the case of an occurrence as described above, of a threat to the security of electricity supplies, the provisions contained in Art. 11c(2-6) of the Energy Law find application. In accordance with these provisions in the case of the occurrence of a threat to the security of electricity supplies the transmission system operator (TSO) or the operator of the combined system has at their disposal two types of measures. The operator undertakes the first type of measure in cooperation with users of the electricity system. Such measures are 'all possible efforts in utilizing available means in the aim of removing the threat and preventing its negative outcomes'. From the wording of the provision of Art. 11c(2)(1) it results that undertaking such type of measures is the duty of the operator in the event when there appears a situation of threat to the security of energy supplies. Undertaking the second type of measures is at the operator's discretion - the decision to undertake them was left by the legislator to the operator of the transmission system or combined system. In accordance with Art. 11c(2)(2) the operator may introduce on the territory of Poland or its part limitations in the supply and collection of electricity. These limitations can be binding until the time executive provisions come into effect, ones issued on the basis of Art. 11(7) of the Energy Law ${ }^{13}$, but for no longer than 72 hours.

The remaining provisions contained in the described article place upon the operator of the electricity transmission system or the combined electricity system a series of obligations of an information character. Above all, in the case of a threat to the security of electricity supplies the operator is obliged to immediately inform the minister responsible for economic affairs and the URE President of the occurrence of such threat and of the means and measures undertaken in the aim of removing the threat and preventing its negative consequences. Moreover, the operator may declare the necessity of introducing limitations on the basis of the ordinance of the Council of Ministers issued in reliance on the statutory disposition contained in Art.

13 In accordance with Art. 11(7) of the Energy Law: 'The Council of Ministers, on the motion of the minister responsible for economic affairs, by way of a order, may introduce for a defined period on the territory of the republic of Poland, or its part, limitations in the sale of solid fuels and in the supply and collection of electricity and heat' in the event of a threat to the energy security of the republic of Poland that rests upon a long-term lack of balance on the fuel and energy market, of security in electricity supplies, safety of persons, or the occurrence of significant material losses. 
11(7) of the Energy Law. Declaration by the operator of this type of necessity is essential above all in regards to the information conveyed to the minister responsible for economic affairs, for it is on his motion that the council of Ministers issues an ordinance in the matter of introducing a limitation in the sale of solid fuels and in the supply and collection of electricity and heat.

In the case when the Council of Ministers introduces limitations in the supply and collection of energy the operator of the transmission system or the combined system within a period of 60 days from the day of their suspension submits to the minister responsible for economic affairs and the URE President a report whose elements were exhaustively mentioned in the provision of Art. 11c(4) in fine and Art. 11c(5). These reports are taken into consideration in the reports of the minister for economic affairs from the monitoring $f$ the security of electricity supplies. The legislator placed demands concerning the subject of the report in two separate provisions, which however (from the perspective of legislative technique) is unnecessary.

\section{Removing the state of threat to the security of electricity supplies}

The provision of Art. 11d. of the Energy Law defines the means and measures which may I are to be applied by the operator of the electricity transmission system or the combined electricity system for the removal of a threat to the security of electricity supplies. These measures were defined by the legislator in a non-random order, but rather in a hierarchical manner. The grounds for the act on amending the Energy Law and on amending certain other acts emphasizes the gradation of means the operator may apply: 'In the first instance means are indicated that serve to balance the supplies with the collection of electricity in the electricity system. After exhausting all possible measures to cover the needs of recipients for electricity the TSO may issue recommendations to final recipients concerning limitations in the collection of electricity or interrupt its supply, in accordance with the plans for limitation, discussed in Art. 11(6a)'14.

In accordance with this provision, in a situation when a threat to the security of energy supplies occurs, the operator of the transmission system of the combined system undertakes the following particular measures:

- issues to the generator orders to instigate, set aside, alter the load, or cut off from the grid the generative unit centrally controlled;

- carries out intervention purchases of power of electricity; he issues to the proper operator of the electricity distribution system orders to instigate,

14 From the grounds to the Act of January 8, 2010 on amending the Energy Law and on amending certain other acts, Sejm print no. 2176, p. 33. 
set aside, alter the load, or cut off from the grid the generative unit connected to the distribution grid in the area of his operation, when said unit is not a generative unit centrally controlled;

- issues to the appropriate operator of the electricity distribution system orders to reduce the amount of collected electricity by end users connected to the distribution grid in the area of his operation, or to interrupt the flow of electricity to an essential number of end users connected to the distribution grid in that area;

- after having exhausted all possible measures intended to cover the electricity needs, issues to end users connected directly to the transmission grid orders to reduce the amount of collected electricity or to cut off from the grid equipment and installations belonging to those recipients, in accordance with the plan for introducing limitations;

- carries out a reduction of the size of transmission capacity of the intersystem exchange.

Closer analysis in required to indicate the hierarchy of applying concrete measures that may be applied by the operator of the transmission system or the combined one in a situation when there occurs a threat to the supplies of electricity. Above all we need observe that the catalogue of measures mentioned in Art. 11d(1) of the Energy Law gas an open character. We may therefore divide the measures at the disposal of the operator of a transmission system of combined one into measures defined in the act and measures outside it, about which priority in application is to be ascribed to the measures defined by statute. Among that group of measures special attention need be paid to the measure defined in Art. 11d(1)(5) of the Energy Law - namely, issuing orders to final recipients connected directly to the transmission grid to reduce the amount of electricity been drawn or to cut off from the grid equipment and installations belonging to those recipients, in accordance with the plan for introducing limitations. In accordance with the wording of the entire provision of Art. 11d(1) of the Energy Law we need recognize that this measure finds application after having exhausted both the measures indicated in Art. 11d(1) (1-4) and (6) and the measures outside the act.

In accordance with the provision of Art. 11d(4) the operators of electricity systems cover the costs borne by the energy undertakings dealing in the generation of electricity in connection with application of the measures defined in Art. 11d(1) of the Energy Law. In regard to the lack of a definition of the concept 'costs borne by the energy undertakings dealing in the generation of electricity' this provision remains in a relationship with the provision of Art. 11e(1) of the Energy Law, in accordance with which the operator of the transmission system or the combined system, which as a result of circumstances for which he is responsible, introduced limitations or permitted sloppiness in 
carrying out an appraisal of the fittingness of introducing said limitations, and answers for the damages arisen among users of the national electricity system, including recipients of electricity connected to the grid on the territory of the Republic of Poland affected by limitations, as a result of application of means and measures described in Art. 11c and 11d of the Energy Law. As the basic criterion for distinguishing the costs borne by the energy undertakings dealing in the generation of electricity in connection with the application of measures defined in Art. 11d(1) of the Energy Law, as well as the damage suffered by them as a result of the application of means and measures described in Art. 11c and Art. 11d of the Energy Law, the criterion must be recognized of the operator's error in applying the indicated means and measures. In the case of the lack of fault on the part of the operator, he is obliged to cover only the costs borne by the generator, however, in the case of the operator's error he shall answer to the generator on the bases defined in Art. 11e of the Energy Law $^{15}$.

In light of the provision of Art. 11d(5) the costs borne by the operators of the electricity system connected with the undertaking of measures indicated in para. 1 of the here described provision are for that operator justified costs of the measures described in Art. 45(1)(2) of the Energy Law. In accordance with the provision here discussed the operators may reckon the amount of the costs paid for the above described reasons toward 'covering the justified costs borne by the operators of the transmission and distribution systems in connection with the realization of their tasks' in calculating the tariff for electricity.

\section{The new powers and obligations of the URE President}

In regard to the here described amendment to the Energy Law, the catalogue of powers and obligations of the URE President (Art. 23 of the Energy Law) underwent change. Below are listed the most important changes introduced, ones that represent a consequence of the changes to the Energy Law described in this paper. Thus, they do not require special discussion, but merely a full listing.

To the catalogue contained in the provision of Art. 23 of the Energy Law were added the following powers and obligations of the URE President:

- approval of the operators' Compatibility Program;

- approval of the full Instructions for the Movement and Exploitation of the Transmission Grid and the Instructions for the Movement and Exploitation of the Distribution Grid;

15 Cf. F. Elżanowski [in:] M. Swora, Z. Muras (eds), Prawo energetyczne. Komentarz [Energy law. Commentary], Warszawa 2010. 
- designation of the operators of electricity and gas systems;

- designation of the operators for the grids belonging to other energy undertakings;

- conducting auctions for new generative powers or enterprises reducing the need of electricity;

- the obligations connected with the security of the National Energy System (KSE), involving i.a., monitoring the activities of operators in the case of threats to the security of electricity supplies;

- issuing certificates of origin for energy from biogas and supervision of the obligation to carry out the obligation of purchasing those certificates by energy undertakings;

- monitoring and supervision of the generators of electricity and heat, specifically their reserves of fuel in an amount assuring the maintenance of continuity of electricity and heat supplies for recipients;

- monitoring the observance of the obligation to sell electricity by way of open auction or by a goods market and internet trade platform by the generators of electricity (the obligation to sell $15 \%$ of the electricity generated in a given year) and by generators of electricity having the right to receive compensation on account of stranded costs (the obligation to sell the entirety of electricity);

- the power to invalidate an auction for the sale of electricity;

- to free generators of electricity from the obligation to sell their produced electricity by public trade;

- declaring median prices for sale of: electricity generated in high-efficiency cogeneration; electricity on the competitive market, and the way it is reckoned; heat generated in generating units belonging to undertakings possessing a concession, but are not cogeneration units.

Here we need note that the amendment here described affected a partial implementation of the determinations of the Third Energy Package (time period for completion - March 3, 2011) and strengthened the legal position of the URE President.

As a consequence of the indicated powers and obligations of the URE President, which correspond accordingly to the obligation of energy undertakings, the catalogue of offenses and sanctions contained in Art. 56 of the Energy Law was expanded. 


\section{Introducing the requisite public trade of electricity by generators in the aim of preventing the phenomenon of unjustified increase of stranded costs}

\subsection{Ratio legis for introducing the obligation of public trade of electricity and the subject and object scope of the obligation}

By virtue of Art. 49a the legislator introduced to the Energy Law the obligation to carry out the trade of electricity in a statutorily defined way aimed at assuring open and public trade of energy and in consequence an improvement of the conditions for competition reigning on the electricity market in Poland. In accordance with the grounds for the governmental draft of the act on amending the Energy Law and on amending certain other acts, the introduction of the obligation to carry out trade in electricity in a public way and on open bases is intended to eliminate the phenomenon of jacking up the amounts of compensation being received on account of stranded costs. This phenomenon involves the generator selling electricity to a trade company operating within the framework of the same capital group for a price significantly lower than the price established for those outside the group (i.e., the market price), and this leads to lowering the income of the generator, which is then factored into the calculations to correct the amount of compensation paid out to cover the stranded costs. The introduction of the regulation contained in Art. 49a is therefore designed to exclude the possibility of abusing the public assistance extended to energy undertakings by virtue of the act of June 29, 2007 on the bases for covering the costs arisen among generators in connection with the premature dissolution of long-term contracts (hereafter, LTC) for the sale of power and electricity (the so-called act on dissolving LTCs) ${ }^{16}$.

The compensation paid to energy undertakings on account of stranded costs after the dissolution of long-term contracts was qualified as public assistance. The long-term contracts themselves became a significant problem at the moment Poland joined the European Union, as they disrupted competition on the energy market and were at variance in this regard with community law. They had a selective character and assured profits only to those power plants and energy producers which signed them, and above all they strengthened the monopolist position of the PSE company - Polskie Sieci Elektroenergetyczne. Moreover, PSE - Operator S.A. is a company belonging to the state treasury, which the European Commission treats as a state institution. For these reasons the LTC were recognized in the opinion of the European Commission as

16 Journal of Laws 2007 No. 130, item 905, as amended.

VOL. 2011, 4(5) 
impermissible public assistance at variance with the European Treaty ${ }^{17}$. In July 2001 in regard to the fears concerning possible improprieties the European Commission issued a 'Communique concerning the methodology of analyzing public assistance connected with the phenomenon of stranded costs'. All the above indicated factors negatively influenced the functioning of the competitive electricity market in Poland.

In accordance with para. 1 of the provision here described the energy undertaking dealing in the generation of electricity is obliged to sell no less than $15 \%$ of the electricity generated in a given year on the goods markets in the understanding of the act on goods markets or on the market regulated in the understanding of the act of July 29, 2005 on trade in financial instruments. However, in accordance with para. 2 an energy undertaking dealing in the generation of electricity and having the right to receive funds for covering stranded costs on the basis of the act on dissolving LTCs is obliged to sell generated electricity not embraced with the obligation described in para. 1 in a way assuring public, equal access to such energy, by way of an open auction, on an internet platform on a regulated market in the understanding of the act of July 29, 2005 on trade in financial instruments or on goods markets in the understanding of the act on goods markets.

In the aim of carrying the proper qualification of subjects which are embraced with the obligation resulting from Art. 49a(1) and (2) of the Energy Law the subject amendment also introduced a change in the definition of the end user [Art. 3(13a) of the Energy Law]. In the previous wording of the provision in question the end user was defined as the recipient carrying the purchase of fuel or energy for their own use. The Act of January 8, 2010 on amending the Energy Law and on amending certain other acts specified that one's own use does not include electricity purchased in the aim of using it for generation, transmission, or distribution.

\subsection{Allowable forms for trade in electricity by virtue of Art. 49a para. 1 and 2 of the Energy Law}

\section{The goods market and the regulated market}

In its definition of the goods market and the regulated market the provision of Art. 49a of the Energy Law refers us to the proper acts in this scope. The definition of the goods market is contained in Art. 2 item 1 of the act on goods markets. In accordance with the provision here discussed the goods market

17 A. Panek, M. Syroka, 'Program restrukturyzacji kontraktów długoterminowych - nowe podejście' ['The program for restructuring long-term contracts - a new approach'] (2005) 2 Biuletyn URE. 
is 'a set of people, equipment, and technical means assuring all participants of trade identical conditions for concluding market transactions and identical access in the same time to market information, and in particular to information on rates and the prices of market goods and turnover of market goods'. In the understanding of Art. 2 item 2 lit. b) of the act on goods markets energy is a market good.

The definition of the regulated market is contained in Art. 14(1) of the Act of July 29, 2005 on trade in financial instruments. In light of this definition the regulated market is a permanently operating system of trade in financial instruments permitted to such trade that assures investors universal and equal access to market information in the same time by associating offers for buying and selling financial instruments, and identical conditions for purchasing and selling such instruments: it is organized and subject to oversight by the proper organ on bases defined in the provisions of the act, and it is recognized by the member country as fulfilling those conditions, and indicated to the European Commission as a regulated market.

\section{Auction}

The auction, as one of the forms of trade permitted for carrying out the statutory obligation to trade energy, is an institution of civil law. The specific procedure for organizing and conducting auctions will be defined by the ordinance issued by the minister responsible for the economy on the basis of statutory delegation contained in Art. 49a(12) of the Energy Law. The general conditions for organizing and conducting auctions are contained however in the act of April 23, 1964 of the Civil Code (Art. 701-721) and in Art. 49a(10-12). Therefore, in matters unregulated in the ordinance, provisions of the Civil Code will find application.

The provision of Art. 49a(10) contains a catalogue of subjects that may organize auctions whether for purchases or for the sale of electricity: energy undertakings dealing in the generation of electricity and having the right to receive funds for covering stranded costs on the basis of the act on dissolving LTCs, final recipients and the subject operating on its behalf. As it results from the wording of Art. 49a(10) and (11) the organizing and conducting of an auction may be commissioned to third-party subjects by both generators and recipients of energy.

In accordance with Art. 49a(11) of the Energy Law an auction for the sale of electricity organized and conducted by an energy undertaking or a subject operating at its behest is subject to the oversight of the URE President in terms of agreement with the way and manner of organizing and conducting an auction as defined in the ordinance issued by the minister responsible for 
economic affairs. When it is stated that an auction was conducted not in accord with these provisions, the URE President may declare an auction invalid. The provision contained in Art. 49a(11) speaks about 'the way and means of organizing and conducting an auction', and thus the scope of activities subject to oversight on the part of the regulatory organ is very broad.

We need stress the fact that this provision does not concern auctions for the purchase of electricity, i.e., auctions organized by recipients of energy. In comparing the wording of Art. 49a(2) and Art. 49a(11) one may observe that the generator that has the right to receive funds for covering stranded costs on the basis of the act of June 29, 2007 on the bases for covering the costs arisen among producers in regard to premature dissolution of long-term contracts for selling power and electricity may carry out the statutory obligation by way of sale of energy both at auction for purchase and at auction for sale of energy organized by the generator, which fact does not concern the auction for purchasing energy. However, both forms of trade pose a balanced opportunity for carrying out the obligation resulting from Art. 49a para. 2 of the Energy Law $^{18}$.

\section{The internet trade platform}

The definition contained in Art. 49a(3) of the Energy Law of an internet trade platform has a general character and defines only its basic features. One supplement of this definition is found in para. 4, which indicates which conditions for carrying our transactions should be assured to subjects making avail of internet trade platforms. Moreover, the conditions which are to be met by an internet trade platform will be further clarified in an ordinance of the minister responsible for economic affairs, a delegation to the issuance of which was contained in Art. 49a(12) of the Energy Law (as discussed above).

As already mentioned above, this ordinance is targeted at clarifying the definition of an internet trade platform. Thus, the definition of the features of an internet trade platform and of the conditions for trade via this medium is comprised of three elements: a classic definition contained in Art. 49a(3), a non-classic definition contained in para. 4 and provisions contained in the ordinance of the minister responsible for economic affairs concerning the way and manner of organizing and conducting an auction and the sale of electricity on an internet trade platform.

In accordance with the premise of the legislator, the subjects conducting internet trade platforms are obliged to assure participants of turnover: openness

18 Z. Muras, F. Elżanowski [in:] Prawo energetyczne. Komentarz [Energy law. Commentary], M. Swora and Z. Muras [eds.], Warszawa 2010. 
of operating principles; openness of fees collected; identical conditions for concluding transactions for all participants in trading and access to market information in the same time. The concept of openness of operating principles and the concept of openness of fess are to be understood as openness toward all those interested, not only the participants in trading on internet trade platforms. In consequence it need be recognized that information such as the rules for the operation of an internet trade platform and the table of fees and the way fees are applied are to be open to public view.

The matter of a mistake in the editing of this provision also requires discussion, for in Art. 49a(2) we read '(...) on an internet trade platform on a regulated market (...)". The intention of the legislator is not in doubt, as it was to establish internet trade platforms and regulated markets as distinct forms for trading in electricity. In the provision here discussed there was no comma as would have separated the two expressions from one another. In result of this the literal reading of the provisions leads to the conclusion that carrying out the obligation of Art. 49a(2) may occur by selling electricity through the medium of an internet trade platform functioning within the framework of a regulated market. Thus, in light of Art. 49a(2) the internet trade platforms that do not operate within the framework of a regulated market do not meet the statutory requirements. However, it must be stressed that legislative work is being completed in the aim of correcting this mistake in the editing of the provision.

\section{The manner for carrying out the obligation resulting from Art. 49a para. 1 and 2 of the Energy Law}

It must be underlined that the object scope of the provision of Art. 49a(2) in comparison with Art. 49a(1) is significantly narrower. However, the subject scope and the scope of opportunity for carrying out the obligation of public trade in electricity is broader. Art. 49a(2) concerns the whole of the electricity generated in a given year by generators having the right to receive funds for covering stranded costs and in regards to $85 \%$ of the energy they generate this gives the possibility to sell it in another way than on the goods market or the regulated market. The provision examined here does not contain in this regard any percent thresholds, nor any quantitative thresholds determining the amount of obligation in regards to particular forms of trade. This means that a given generator that has the right to receive funds for covering stranded costs may both sell $100 \%$ of the energy it generates in a given year through the medium of a goods market $(15 \%$ in the framework of carrying the obligation of Art. $49 \mathrm{a}(1)$ and $85 \%$ in the framework of carrying out the obligation of Art. 
$49 \mathrm{a}(2)$ and sell $15 \%$ of the generated energy on the market, and the remaining $85 \%$ sale e.g., exclusively at auction.

We need note that the shape of the obligation laid upon the generators of energy posits a certain element of forecasting, as the energy undertaking, in selling energy through the medium of the goods market or on the regulated market, must accept the premise of what amount of energy it will generate in order to sell it in an amount not less than 15\%. In this regard it is probably necessary to expect increased volumes of energy offered for sale at the close of the calendar year.

Failure to meet the obligations of Art. 49a(1) and (2) of the Energy Law may occur not only as a result of selling too small an amount of electricity in forms foreseen in the act, but also as a result of selling on the goods market or internet trade platform, which do not meet the requirements contained in the acts (whether legislative or executive). The outcome of such a state of affairs will be tantamount to flouting the obligation resultant from Art. 49a(1) and (2), for which Art. 56(3) in connection with Art. 56(1)(32) of the Energy Law foresees sanctions in the form of monetary penalties meted out by the URE President. The amount of such a penalty may not exceed $15 \%$ of the revenues of the penalized business as achieved in the previous tax year. The monetary fine is meted out by the URE President in the form of an administrative decision.

\section{Exemption from the scope of the obligation defined in Art. 49a para. 1 and 2 of the Energy Law}

From the scope of the obligation defined in Art. 49a(1) and (2) of the Energy Law were exempted six categories of electricity. The reasons which led the legislator to make such exemption are indicated by the following issues:

- non-introduction of energy to the electricity system, i.e., supplying it to the recipient by means of a direct line [Art. 49a(5)(1)] or using energy for one's own needs [Art. 49a(5)(4)];

- generating energy embraced with support in the form of certificates of origin [Art. 49a(5)(2) and (3)];

- using of energy by the grid undertakings to carry out statutory tasks [Art. 49a(5)(5)];

- energy generated in a unit of small installation power, exempted from the obligation to obtain a concession for generating electricity [Art. 49a(5) and (6)].

It need be stressed that the indicated exemption is an exemption by virtue of law (ex lege), which means that it is effective on the basis of the very provision of the act and does not require for its effectiveness a solution issued by the 
URE President nor a motion on the part of an energy undertaking. When an energy undertaking exceeds the scope of exemption discussed here, this will result in the energy undertaking's failure to observe the obligation described in Art. 56(1)(32). In regard to Art. 56(3) the URE President then metes out on the undertaking a monetary penalty of an amount up to $15 \%$ of the revenue achieved in the previous tax year.

Moreover, in the provision to Art. 49a(6) of the Energy Law premises were concluded for obtaining an exemption from the obligation of mandatory trading in electricity in legally defined forms. Said exemption is awarded by the URE President on the motion of the energy undertaking. The exemption foreseen in Art. 49a(6) has an optional character for the URE President and concerns only a portion of the electricity generated by the undertaking. The exemption of the energy undertaking from the obligation to sell generated electricity in a statutorily defined way is also carried out in the form of an administrative decision. This is a decision issued in proceedings begun on a motion submitted by an energy undertaking that meets the conditions defined in Art. 49a(6)(1) or (2).

The exemption here discussed may concern both all generators having the obligation to sell $15 \%$ of their energy through the medium of a goods market or on a regulated market as placed on all generators, and those generators having the right to receive funds for covering stranded costs, upon which rests the obligation to sell the entirety of the generated energy on the bases of public trade. The exemption of electricity from the obligation resulting from Art. 49a(1) and (2) may concern energy sold for the needs of carrying out long-term obligations resulting from contracts concluded with financial institutions in the aim of carrying out investments connected with the generation of electricity and energy generated for the needs of the operator of a transmission system, made avail of for the needs of the proper functioning of the national electricity system. The premises conditioning the possibility of exemption of the energy undertaking from the obligation to sell in forms defined in Art. 49a(1) and (2) were however limited in an absolute way by one condition: 'if it does not cause real disruption to the conditions of competition on the electricity market or disruption on the balancing market'.

In the case when the energy undertaking does not obtain the required exemption by virtue of a decision of the URE President and despite this does not sell the generated energy in a way foreseen in Art. 49a(1) and (2), the URE President will mete out to that undertaking a monetary penalty in the amount of 155 of the revenue achieved in the previous tax year [Art. 56(1) (32) in regards to Art. 56(3) of the Energy Law]. 


\section{The information and report obligations}

The provision of Art. 49a(7) of the Energy Law places on the energy undertaking dealing in the generation of electricity obliged to sell $15 \%$ of its generated electricity in a given year the obligation to inform about selling contracts having been concluded. This obligation concerns contracts to sell electricity concluded in a manner that differs from the manners mentioned in para. 1 and 2 of the provision herein discussed, i.e., on a goods market for energy, a regulated market, internet platform, or by way of auction.

In the case of energy undertakings dealing in the generation of electricity and having the right to receive funds for covering stranded costs such information will concern exclusively energy that was exempted from the obligation resultant from Art. 49a(1) and (2) by virtue of Art. 49a(5) and (6) (i.e., exemption by virtue of law or exemption awarded by the URE President). However, in the case of all the remaining undertakings dealing in the generation of electricity the obligation to convey information to the URE President concerns both contracts to sell energy above the $15 \%$ mandatory turnover on a goods market or regulated market, and the scope of energy exempted from the obligation resultant from Art. 49a(1) (also in this case exemption by virtue of law or exemption awarded by the URE President).

The provision of Art. 49a(8) of the Energy Law represents the consequence of Art. 49a(7) and concerns providing for public news the average price of electricity not subject to the obligation resultant from Art. 49a(1) and (2). This is an element of the information obligations resting by virtue of the Energy Law on the URE President. The aim of the provision here discussed is that of transparency and openness in the price of electricity not subject to the obligation to sell defined in Art. 49a(1) and (2).

The report writing obligation of energy undertakings, discussed in Art. 49a(9), represents the realization of a new duty for the URE President. It was introduced by the Act of January 8, 2010 on amending the Energy Law and on amending certain other acts to Art. 23 of the Energy Law, in which is contained the catalogue of competencies of the regulatory organ. Art. 23(4a) places upon the URE President the duty to oversee the carrying out by energy undertakings of the obligations resultant from Art. 49a(1) and 2. The basic instrument serving the regulatory organ to carry out this duty is that of the indicated report writing obligation placed upon the energy undertakings dealing in the generation of electricity.

The provision here discussed does not contain any indications regarding the subject of the reports concerning the realization of the obligations resultant from Art. 49a(1) and (2). However, we may assume that such a report is to contain elements analogous to the information discussed in Art. 49a(7), i.e., 
the parties to the contract, the amount and price of electricity, and the period for which the contract was concluded. Such a report should, however, remain in connection with the model for carrying out transactions, that is, it should be adequate to the characteristics of the given form of trade, e.g., the subject selling energy through the medium of a goods market is not able to indicate the second party to the contract.

The requisite information is embraced with internal openness, thus the obligation foreseen in the discussed provisions does not violate the secret of the undertaking. What is more, this obligation results from provisions of a detailed character, which also excludes collision in this scope.

\section{The Act of April 9, 2010 on making available economic information and exchanging economic data}

In accordance with the provision of Art. 1 of the act on making available economic information and exchanging economic data, the following principles are stressed: making available economic information concerning payment credibility; exchange of data concerning payment credibility with institutions having at their disposal such information and having their headquarters in member-state countries of the European Union and in states that are party to the European Economic Area; the creation and operation of an economic information office; the publication, preservation, updating, and removal of economic information and carrying out oversight regarding the economic information office.

The act here discussed, in chapter 7, entitled, 'Changes in binding provisions, transitional and final provisions' in Art. 52 contains a provision amending the Energy Law. By virtue of this provision to the Energy Law Art. 62a was amended in accordance with which the energy undertaking may make available data about the recipient on the bases and in a manner defined in the act on making available economic information and exchanging economic data. The provision at issue was placed in the final part of the Energy Law, in chapter 7, entitled 'Changes in binding provisions, transitional and final provisions'. We need note that in the intention of the legislator the amended provision represents the basis for conveying by the energy undertaking economic data to economic information offices. The provision here discussed has therefore the character of a materiallegal provision, and thus its placement in the transitional and final provisions does not find justification and must be deemed a mistake on the part of the legislator.

VOL. 2011, 4(5) 


\section{Summary}

As the present paper demonstrates, the Act of January 8, 2010 on amending the Energy Law and on amending certain other acts has introduced significant changes to the functioning of the electricity market in Poland. The solutions introduced by its virtue should be appraised altogether positively. During the elaboration of the text of the amendment the legislator was guided by clearly marked objectives and applied adequate means for their realization. In this regard, and thanks to e.g., the introduction of the obligatory public trading in electricity, the phenomenon was eliminated of increasing the amount of compensation being received on account of stranded costs, and the introduction of the 'payment in the form of a fee' for connecting sources to the electricity grid allowed a curbing of the ploy of reserving a defined amount of power in a given location, and also of trade in the conditions for connection to the electricity grid.

The solutions which have proved themselves in practice will no doubt be carried over by the legislator to the planned new Energy Law. The solutions that will fulfill their role and whose subsequent functioning the legislator will recognize as unessential will most probably not be continued. 